Journal of Back and

Musculoskeletal Rehabilitation

\title{
Calendar
}

\section{Anatomical Workshops in Orthopaedic Surgery 1998/99}

Surgical approaches to the foot and ankle 13-14 July 1998

Convenor: Mr D Grace, Chase Farm Hospital

Mr D Singh, Royal National Orthopaedic Hospital

Location: The Hill Surgical Workshop, The Royal College of Surgeons of England, 35-43 Lincoln's Inn Fields, London, WC2A 3PN.

Information: Sophie Mitchell on tel: (44) 171 312 6693; fax: (44) 171973 2118; e-mail: smitchel@rcseng.ac.uk

Ilizarov method: basic and intermediate 1-5 September 1998

Convenor: $\quad$ Mr H Simpson, Oxford

Location: The Royal College of Surgeons of England, 35-43 Lincoln's Inn Fields, London, WC2A 3PN.

Information: Victoria Grice on tel: (44) 171973 2105; fax: (44) 171973 2117; e-mail: vgrice@rcseng.ac.uk

Transoral approaches for skull base surgery 28-30 September 1998 \& 28-30 October 1999

Convenor: Mr H A Crockard, National Hospital for Neurology and Neurosurgery

Location The Hill Surgical Workshop, The Royal College of Surgeons of England, 35-43 Lincoln's Inn Fields, London, WC2A 3PN.

Information: Sophie Mitchell on tel: (44) 171312 6693; fax: (44) 171973 2118; e-mail: smitchel@rcseng.ac.uk

Precutaneous and minimally invasive spine surgery 19-21 October 1998

Convenor: Mr J Johnson, Royal National Orthopaedic Hospital

Mr J O’Dowd, Frimley Park Hospital

Mr J Shepperd, Conquest Hospital

Mr M Sullivan, Royal National Orthopaedic Hospital

Location: The Royal College of Surgeons of England, 35-43 Lincoln's Inn Fields, London, WC2A 3PN.

Information: Victoria Grice on tel: (44) 171973 2105; fax: (44) 171973 2117; e-mail: vgrice@rcseng.ac.uk

A foundation course in locking and nailing 27-29 October 1998

Convenor: $\quad$ Mr A Cross, City Hospital, Sunderland

Location: The Royal College of Surgeons of England, 35-43 Lincoln's Inn Fields, London, WC2A 3PN.

Information: Victoria Grice on tel: (44) 171973 2105; fax: (44) 171973 2117; e-mail: vgrice@rcseng.ac.uk 
Cervical spine stabilisation for deformity and tumours 9-11 November 1998 \& 8-10 November 1999

Convenor: $\quad \mathrm{Mr} \mathrm{H}$ A Crockard, National Hospital for Neurology and Neurosurgery

Mr B Taylor, Royal National Orthopaedic Hospital

Location: The Hill Surgical Workshop, The Royal College of Surgeons of England, 35-43 Lincoln's Inn Fields, London, WC2A 3PN.

Information: Sophie Mitchell on tel: (44) 171312 6693; fax: (44) 171973 2118; e-mail: smitchel@rcseng.ac.uk

Distal radial fractures 13 November 1998

Convenor: Ms M McQueen, The Royal Infirmary of Edinburgh

Mr N Citron, St Helier Hospital

Mr J Shepperd, Conquest Hospital

Location: The Royal College of Surgeons of England, 35-43 Lincoln's Inn Fields, London, WC2A 3PN.

Information: Sue Rownes on tel: (44) 171312 6631; fax: (44) 171973 2117; e-mail: srownes@rcseng.ac.uk

Advanced techniques in arthroscopic knee surgery 11-12 \& 14-15 January 1999

Convenor: $\quad$ Mr Robin Allum, Heatherwood and Wexham Park Hospitals Trust

Mr Chris Dodd, Nuffield Orthopaedic Centre

Location: The Hill Surgical Workshop, The Royal College of Surgeons of England, 35-43 Lincoln's Inn Fields, London, WC2A 3PN.

Information: Sophie Mitchell on tel: (44) 171312 6693; fax: (44) 171973 2118; e-mail: smitchel@rcseng.ac.uk

Open surgery of the shoulder 9-10 February 1999

Convenor: Mr Cormac Kelly, Robert Jones and Agnes Hunt Orthopaedic Hospital Mr Tim Bunker, Princess Elizabeth Orthopaedic Centre

Location: The Hill Surgical Workshop, The Royal College of Surgeons of England, 35-43 Lincoln's Inn Fields, London, WC2A 3PN.

Information: Sophie Mitchell on tel: (44) 171312 6693; fax: (44) 171973 2118; e-mail: smitchel@rcseng.ac.uk

Revision hip surgery 1-2 March 1999

Convenor: $\quad$ Mr Howard Ware, Chase Farm Hospital

Location: The Hill Surgical Workshop, The Royal College of Surgeons of England, 35-43 Lincoln's Inn Fields, London, WC2A 3PN.

Information: Sophie Mitchell on tel: (44) 171312 6693; fax: (44) 171973 2118; e-mail: smitchel@rcseng.ac.uk

Approaches to the thoracic and lumber spine 29-31 March 1999

Convenor: $\quad$ Mr B Taylor, Royal National Orthopaedic Hospital

Location: The Hill Surgical Workshop, The Royal College of Surgeons of England, 35-43 Lincoln's Inn Fields, London, WC2A 3PN.

Information: Sophie Mitchell on tel: (44) 171312 6693; fax: (44) 171 973 2118; e-mail: smitchel@rcseng.ac.uk

Primary knee replacement workshop March 1999 t.b.c.

Convenor: $\quad \mathrm{Mr}$ C Dodd, Nuffield Orthopaedic Centre

Location: The Royal College of Surgeons of England, 35-43 Lincoln's Inn Fields, London, WC2A 3PN.

Information: Victoria Grice on tel: (44) 171973 2105; fax: (44) 171973 2117; e-mail: vgrice@rcseng.ac.uk 
Advanced knee replacement techniques March 1999 t.b.c.

Convenor: $\quad \mathrm{Mr} \mathrm{C}$ Dodd, Nuffield Orthopaedic Centre

Location: The Royal College of Surgeons of England, 35-43 Lincoln's Inn Fields, London, WC2A 3PN.

Information: Victoria Grice on tel: (44) 171973 2105; fax: (44) 171973 2117; e-mail: vgrice@rcseng.ac.uk

Management of sports injuries 13-14 April 1999

Convenor: $\quad$ Mr R Hackney, British Orthopaedic Sports Trauma Association

Location: The Royal College of Surgeons of England, 35-43 Lincoln's Inn Fields, London, WC2A 3PN.

Information: Sue Rownes on tel: (44) 171312 6631; fax: (44) 171973 2117; e-mail: srownes@rcseng.ac.uk

'Interface 99': bioactive implants, bone metabolism \& bone healing 10-11 December 1999

Convenor: $\quad$ Mr R Atkins, Bristol Royal Infirmary

Mr G Molnar, Conquest Hospital

Mr J Shepperd, Conquest Hospital

Location: The Royal College of Surgeons of England, 35-43 Lincoln's Inn Fields, London, WC2A 3PN.

Information: Sue Rownes on tel: (44) 171312 6631; fax: (44) 171973 2117; e-mail: srownes@rcseng.ac.uk 